\title{
PS: Political Science and Politics Reviewers, 2011
}

T $\mathrm{n}$ 2011, PS: Political Science and Politics published articles covering a vast range of topics. The journal's commitment to publishing articles on pedagogy and the profession, as well as exemplary topical scholarship on a spectrum of issues, call for an equally broad stable of reviewers. PS cannot publish such diverse work without the outstanding work (and openmindedness) of our peer reviewers. The peer-review process relies on the professionalism and generosity of those who contribute their time and knowledge to read and evaluate the work of others. In 2011, 451 reviewers were asked to review, 132 agreed and completed their review. The editor and staff of $P S$ thank the following scholars who served as manuscript reviewers between January 1, 2011, and December 31, 2011.

Regina M. Abrami, Harvard Business School

Gary Ackerman, University of Maryland, College Park

Martin J. Adamian, California State University, Los Angeles

Brian E. Adams, University of California, Irvine

Robert Kaufman Adcock, George Washington University

Tony Affigne, Providence College

Robert B. Albritton, University of Mississippi

Jose Aleman, Fordham University

Robert M. Alexander, Ohio Northern Univeristy

Dwight D. Allman, Baylor University

David Altman, Pontifica Universidad Catolica de Chile

S. M. Amadae, Ohio State University

Thomas Ambrosio, North Dakota State University

J. Theodore Anagnoson, California State University, Los Angeles

David R. Andersen, University of Maryland

Brian B. Anderson, Mississippi University for Women

Janni L. Aragon, University of Victoria

Robert K. Arakaki, University of Hawaii, Manoa

Kevin Arceneaux, Temple University

Philip Ardoin, Appalachian State University

Ofer Arian

Victor Asal, University at Albany, SUNY

Edward Ashbee, Copenhagen Business School

Stephen C. Baker, Jacksonville University

Mary Ellen Balchunis, La Salle University

Thomas J. Baldino, Wilkes University

Kevin G. Barnhurst, University of Illinois, Chicago

David M. Barrett, Villanova University

Shana B. Bass, California State University, San Marcos

David R. Beam, Illinois Institute of Technology

Emily Ann Beaulieu, University of Kentucky
Kris Aaron Beck, Gordon College

Andrew Bennett, Georgetown University

Stanley P. Berard, Lock Haven University of Pennsylvania

John C. Berg, Suffolk University

Jeffrey L. Bernstein, Eastern Michigan University

Koop Berry, Walsh University

Amy E. Black, Wheaton College

Keith Boeckelman, Western Illinois University

Holly Brasher, University of Alabama, Birmingham

Craig Leonard Brians, Virginia Tech

Michelle D. Brophy-Baermann, Rhode Island College

Courtney Brown, Emory University

Kevin M. Bruyneel, Babson College

James E. Campbell, University at Buffalo, $S U N Y$

Giovanni Capoccia, University of Oxford

Miguel Centellas, University of Mississippi

Theodore Chadjipadelis, Aristotle University

Matthew A. Childers, University of California, San Diego

Alexandra Cole, California State University, Northridge

John J. Coleman, University of Wisconsin, Madison

Michael Comiskey, Pennsylvania State University

Charles Cornelius Conyers, US Office of Personnel Management

Austin Lane Crothers, Illinois State University

Coutenay W. Daum, Colorado State University

James W. Davis, University of St. Gallen

Matthew De Bell, Stanford University

Matthew J. Dickinson, Middlebury College

Alesha E. Doan, University of Kansas

Gary R. Donato, Massachusetts Bay Community College

John Echeverri-Gent, University of Virginia

Laurel Elder, Hartwick College

Colin Elman, Syracuse University

James W. Endersby, University of Missouri, Columbia
Kevin M. Esterling, University of California, Riverside

Victoria A. Farrar-Myers, University of Texas, Arlington

Joel S. Fetzer, Pepperdine University

Jeffrey A. Fine, Clemson University

Benjamin O. Fordham, University at Binghamton, SUNY

Kenneth W. Foster, Concordia College

Robert J. Friedrich, Franklin and Marshall College

James C. Garand, Louisiana State University

J. David Gillespie, College of Charleston Johnny Goldfinger, Marian University

Fred I. Greenstein, Princeton University

Jennifer M. Hazen, University of Texas, Austin

Charles J. Helm, Western Illinois University

Tony L. Hill, Massachusetts Institute of Technology

Matthew S. Hirshberg

Donna R. Hoffman, University of Northern Iowa

Philip J. Howe, Adrian College

Stephen A. Jessee, University of Texas, Austin

Gary Alan Johnson, Weber State University

H. Whitt Kilburn, Grand Valley State University

Edward L. Lascher, California State University, Sacramento

Mika LaVaque-Manty, University of Michigan, Ann Arbor

Christopher N. Lawrence, Virginia Tech

William M. LeoGrande, American University

Angela K. Lewis, University of Alabama, Birmingham

Jeremy R. T. Lewis, Huntingdon College

Peter John Loewen, University of Toronto

Renee Marlin-Bennett, Johns Hopkins University

Dale Rogers Marshall, Wheaton College

Seth E. Masket, University of Denver

Manus I. Midlarsky, Rutgers University

Charles L. Mitchell, Grambling State University 
Hans Noel, Georgetown University

Eric Novotny, CRDF

Robert C. Oberst, Nebraska Wesleyan University

Laura R. Olson, Clemson University

John David Rausch, West Texas A\&M Univesity

Andrew Rehfeld, Washington University, St. Louis

Joseph W. Roberts, Roger Williams University

Daniel Rubenson, Ryerson University

Maria Rost Rublee, University of Auckland
Charles R. Venator Santiago, University of Connecticut, Storrs

Kanishkan Sathasivam, Salem State University

Carisa R. Showden, University of North Carolina, Greensboro

Charles Anthony Smith, University of California, Irvine

Jeffrey Sosland, American University Mark Souva, Florida State University Bonnie Stabile, George Mason Universit Allan C. Stam, University of Michigan Katina R. Stapleton
Jonathan R. Strand, University of Nevada, Las Vegas

Dwight V. Toavs, National Defense University

M. Stephen Weatherford, University of California, Santa Barbara

Peter W. Wielhouwer, Western Michigan University

Antoine Yoshinaka, American University

If you are interested in reviewing let us know.Contact PS@apsanet.org.

\title{
Notes from the Editor: PS: Political Science and Politics
}

\author{
PS: What You Are Reading (online)
}

Our publisher's report for PS: Political Science $\mathcal{E}$ Politics for 2011 gives us some insight into what you, our readers, are reading here in the pages of $P S$. In total, more than 101,00o readers completed full-text downloads of online articles in 2011, up nearly $30 \%$ from 2010 and $26 \%$ compared to 2009 figures. This figure only represents electronic downloads; we know that print is very important too and we hope to report on that readership in the future.

Overall, $P S$ still ranks very well against our publishers' other political science and international relations titles.

Among the organizations and institutions that downloaded the most $P S$ articles over the last year were

University of California, Riverside Libraries; Georgia State University; University of California, San Diego Libraries; University of Oxford; Balfour Library (Pitt Rivers Museum)

\section{MOST DOWN-LOADED ARTICLES IN} 2011

The five most-downloaded articles, published in any year, for PS in 2011 were:
Diascro, Jennifer Segal. 2011. "The Job Market and Placement in Political Science in 2009-10." PS: Political Science and Politics 44 (3).

Giles, Michael W., and James C. Garand. 2007. "Ranking Political Science Journals: Reputational and Citational Approaches." PS: Political Science and Politics 40 (4).

Jacobs, Lawrence R. 2010. "What Health Reform Teaches Us about American Politics." PS: Political Science and Politics 43 (4).

Leech, Beth L. 2002."Asking Questions: Techniques for Semistructured Interviews." PS: Political Science and Politics 35 (4).

Knopf, Jeffrey W. 2006. "Doing a Literature Review." PS: Political Science and Politics 39 (1).

\section{THE FIVE MOST DOWNLOADED ARTICLES FOR VOLUME 44 (2011 VOLUME)}

From our volume year recently completed in 2011, the five most downloaded articles for volume 44 are as follows:
Diasco, Jennifer Segal. 2011. “The Job Market and Placement in Political Science in 2009-10." PS: Political Science and Politics 44 (3).

Monroe, Kristen Renwick. 2011. "Ethics in an Age of Terror and Genocide: Identity and Moral Choice." PS: Political Science and Politics 44 (3).

Karpowitz, Christopher F., J. Quin Monson, Kelly D. Patterson, and Jeremy C. Pope. 2011. Tea Time in America? The Impact of the Tea Party Movement on the 2010 Midterm Elections. PS: Political Science and Politics 44 (2).

Sides, John. 2011. The Political Scientist as a Blogger. PS: Political Science and Politics 44 (2).

Perliger, Arie, and Ami Pedahzur. 2011. Social Network Analysis in the Study of Terrorism and Political Violence. PS: Political Science and Politics 44 (1).

We look forward to learning more about what you are reading in 2012.

(continued nex page) 